UDC [664.641.12-026.761:664.64.016.8]

DOI:

D. Zhygunov ${ }^{1}$, Dr. of Technical Sciences, Associate Professor, E-mail: dimius75@gmail.com https://orcid.org/0000-0001-9435-2266, ResearcherID: D-1372-2015, Scopus Author ID: 55820666600 I. Toporash ${ }^{2,3}$, Candidate of Technical Science, https://orcid.org/0000-0001-5165-8070

Y. Barkovska ${ }^{1,2}$, Master, E-mail: ellion.vent@gmail.com https://orcid.org/0000-0001-8627-8721

Y. Yehorshyn', Master, E-mail: yevheniiyehorshyn@gmail.com https://orcid.org/0000-0003-3038-0254

${ }^{1}$ Odessa National Academy of Food Technologies, 112, Kanatna Str., Odessa, 65039, Ukraine

${ }^{2}$ SC Agmintest Control Union, Ovidiopol road, 3, Odessa, 65036, Ukraine

${ }^{3}$ Plant Breeding and Genetics Institute - National Center of Seed and Cultivar Investigation, Ovidiopol road, 3, Odessa, 65036, Ukraine

\title{
COMPARISON OF ALVEOGRAPH CHARACTERISTIC OF FLOUR OBTAINED FROM DIFFERENT TYPES OF COMMON WHEAT AND SPELT WHEAT
}

\begin{abstract}
Practice of processing of new types of wheat is widespread in the world, but it's almost unknown in the CIS countries, because selection for many years aimed at obtaining exclusively high-protein bread-baking varieties of wheat. But not known what technological properties of flour possesses from wheat types of a special intended purpose, and that it's necessary to consider when conducting varietal grinding of such raw material.

The alveograph measures the viscoelastic properties of wheat flour. According to the standard method ISO 27971 the amount of added water is initially calibrated directly as a percentage of dough moisture. This method is designed for standard types of flour and may not be suitable for evaluating the rheological properties of flour with different water absorption capacity. To find out the properties of new types, standard methods may not be suitable, therefore, methods should be studied and adapted if necessary.

To investigate the relationship between water absorption capacity and viscoelastic properties of the dough, alveograph tests were conducted on eight flour samples obtained from different types of wheat. The studies were performed using a standard test (calculated for WAC of flour $=53 \%$ ) and a test with adaptive moistening, for which the amount of added water was calculated according to the water absorption capacity (WAC) of the flour, which was determined on mixolab.

Flour from common red wheat (Kuyalnik) is the benchmark of common bakery wheat and according to the results of standard alveogram has the highest strength $(W)$ and elasticity (Ie) of all samples. The wheat with $W=439 \cdot 10^{-4} \mathrm{~J}$ corresponds to strong wheat $\left(W>200 \cdot 10^{-4} \mathrm{~J}\right)$. The addition of water in accordance with the WAC softens the dough $W=260 \cdot 10^{-4} \mathrm{~J}$, but it's still optimal for bakery purposes. The results of studies of common black wheat (Chornobrova) correlate with the results of wheat Kuyalnik, but the baking properties were worse.

For waxy wheat (Sofiika), the test on the alveograph with adaptive moistening gave her more water, which led to an increase in elasticity $(I e=52.4 \%)$ and extensibility $(L=77 \mathrm{~mm})$ and became closer to an optimal $P / L$ ratio $(0.74)$ that was more suitable for the bake bread (0.8-1.2).

Flour from soft wheat is expected to have average baking properties $\left(W>155 \cdot 10^{-4} \mathrm{~J}\right)$, but in all respects it is slightly better than Chornobrova. Adaptive moistening, unlike the sharp deterioration of rheological characteristic of Chornobrova, does not alter the properties of the Belyava and Oksana dough, due to the low WAC value (53.8\% and $54.0 \%)$. Spelt wheat flour has low strength $\left(W<62 \cdot 10^{-4} \mathrm{~J}\right)$, lower P/L ratio 0.25-0.50 and unsuitable (fluid, sticky) test consistency. All samples of Spelt with adaptive moistening showed similar result - its decrease of $P$ indicator and increase of extensibility $(L)$. In a result we observe decrease of $P / L$ ratio to 0.18-0.29, thus indicating extremely extensible doughs with very little elasticity.

For all samples, with adaptive moistening a decrease in resistance to extension $(P)$ and an increase in extensibility $(L)$ are observed, in a result of the decline in the P/L ratio. Adaptive moistening for common wheat (Kuyalnik) will show the change in $P$ and $L$ and the $P / L$ ratio in real cooking conditions, since the standard alveograph test assesses only the potential of wheat. By adjusting the amount of water, we can achieve optimal dough characteristics for different products. For soft and spelt wheat, adaptive moistening is not necessary, because the WAC and moisture content are the same, and according to the standard of the experiment. It is advisable to carry out an alveograph test with adapted moistening for waxy wheat, that giving it more water, which leads to an increase in elasticity and extensibility, as a consequence, and leading to an optimal P/L ratio that was more suitable for the bake bread (0.8-1.2). Based on its special application, it is necessary to develop specific recommendations for determining its properties on the alveograph.
\end{abstract}

Key words: wheat, spelt, wheat flour, mixolab device, alveograph device, water absorption capacity, rheological properties, adaptive moistening.

\section{Introduction. Formulation of the problem}

Wheat is one of the world's major food crops. Thus, the nutritional value of wheat is of great importance, as it contributes significantly to the human diet in terms of calories and nutrients (Abdel-Aal et al., 1998).

Wheat represented by a large variety of species - about 30 . However, two species of wheat are of practi- 
cal importance: hard or ordinary (Triticum vulgare or Triticum aestivum), and durum (Triticum durum). At present there is considerable interest in the consumption of alternative crops (Berti et al. 2005).

Considering the current requirements and the active growth production of food products, in particular bakery and pasta products, the issue of expanding the range of end-use products of various intended uses is very actuality. This problem can solve by the processing of new types of wheat. They can differ in their technological properties from the usual bread baking wheat and it is not known what must be considered when conducting the grinding of this raw material and its end-use. To find out the properties of new types, standard methods may not be suitable, therefore, methods should be studied and adapted if necessary.

Based on the foregoing, one can assume the necessity of using different types of wheat in the manufacture of bakery and pasta products. Therefore, for the production of confectionery flour, promising raw materials are soft wheat, which characterized by low content of protein, gluten and low water absorption capacity. For the production of the vermicelli can be used waxy wheat, which is characterized by high grain strength, low falling number.

\section{Analysis of recent research and publications}

Wheat produced can be divided into five major classes (Table 1). Each class of wheat has its own characteristics related to milling, baking or other food use described in Marketing Resource Center (2018). Most classes contain both winter and spring varieties.

Table 1. Wheat classes

\begin{tabular}{||c||c||}
\hline \multicolumn{1}{|c||}{ Class } & Uses \\
\hline \hline Hard Red Winter & Bread flour \\
\hline \hline Hard Red Spring & High-protein blending \\
\hline \hline Soft Red Winter & Cakes, cookies, crackers \\
\hline \hline White & $\begin{array}{c}\text { Flour for noodles, crackers, } \\
\text { cereals }\end{array}$ \\
\hline \hline Durum & Pasta \\
\hline
\end{tabular}

In modern agriculture, bread wheat ( $\mathrm{T}$. aestivum) is widely grown all over the world, accounting for $95 \%$ of total wheat grown. The remaining 5\% largely consists of durum wheat (T. durum) (Shewry, 2009). Currently, total around 4000 bread wheat varieties cultivated in the world, with either a spring or winter growth habit (Posner, 2000). However, recently the work has been carried out to develop and spread varieties of soft (confectionery) wheat, as well as wheat varieties for special purposes (Toporash, Rybalka, 2008). It has more starch and less gluten than hard wheat, and it is a good choice for cakes, pastries, desserts, and sauces. Soft wheat preferably do not absorb such high levels of water and are thus selected for low water absorption and thin endosperm cell walls containing lower AX levels (Delcour and Hoseney, 2010).

Soft red winter has a low protein content and used as a blend in multipurpose flours, and for cookies, cakes, donuts and other fine pastries as well as flat breads, and crackers. Soft white wheat is a low-protein wheat that offers high yields. It provides a lighter flour for cakes, crackers, cookies, pastries and it suits Middle Eastern flat breads.

Waxy wheat first developed in 1994 through conventional plant breeding in Japan (Nakamura et al., 1995), and later in Canada (Chibbar et al., 1997) and in the USA (Graybosch, 1998). Waxy wheat also produced through mutagenesis of partial waxy wheats Kanto 107 or Ike (Kiribuchi-Otobe et al., 1997). Physical/chemical properties of waxy wheat starches have been thoroughly studied. Hexaploid waxy wheat starch was found to contain 0.9 to $3.2 \%$ apparent amylose and $0.12-0.29 \%$ lipids (Abdel-Aal et al., 2002), in contrast with 22-25\% amylose and $0.8-1.2 \%$ lipids in nonwaxy wheat starch (Morrison et al., 1984). Tetraploid (durum) waxy wheat starches also showed similar gelatinization and pasting properties (Chakraborty et al., 2004). Although physical and/or chemical properties of waxy wheat starches have been the focus of much research.

Spelt wheat (Triticum aestivum subsp. spelta) is one of the hulled hexaploid wheats which possesses the same genomes as bread wheat (Triticum aestivum L.) (Yan et al. 2003). Hulled wheat is a typical example of an underutilized plant species. These species have a considerable importance in terms of food security and local cultural value, but are relatively unknown and undervalued in commercial production. There are few but marked differences between spelt and common wheat (Campbell 1997, Onishi et al. 2006). The spelt flour is characterized by the yield of about $65 \%$ (Zieliński et al. 2008).

Characterization of rheological properties of dough is effective in processing behavior predicting and in controlling the quality of food products (Song and Zheng, 2007; Abbasi et al., 2011). Although the production of baking products needs the most accurate method in quality evaluation, in order to assess flour-quality attributes, several predictive tests which are closely related to wheat flour quality are frequently used in wheat industry (Colombo et al., 2008).

Rheological characteristics such as elasticity, viscosity and extensibility are important for the milling and bakery industries in view of the prediction of the processing parameters of dough and the quality of the final products. These rheological characteristics change during the breadmaking process and are difficult to measure in definitive terms. Khattak et al. (1974) used the alveograph to evaluate HRS (hard red spring) wheat and reported low and insignificant correlations with the loaf volume. Preston et al. (1987) suggested that part of the problem in assessing the quality of HRS wheat with the alveograph under the standard conditions $(50 \%$ dough absorption) was related to high levels of the starch damage in flours. At most European mills, the alveograph belongs to the most used rheological apparatuses for the flour quality testing.

Water absorption capacity (WAC) - the amount of water needed to hydrate flour components to produce dough with optimum consistency - is one of the most fundamental quality parameter of wheat flour (Bushuk and Békés 2002). Based on this definition, WAC can be interpreting as the function of the relative amounts of the components capable to be hydrated (starch, proteins, pentosans) and their specific water binding capacity. Water absorption capacity determined on the farinograph 
and mixolab devices.

\section{Materials and methods}

Eight samples wheat were investigated: 5 samples of common wheat and 3 samples of spelt wheat. Common wheat represented by such samples, grown at Odessa region in 2018: Kuyalnik (hard red winter), which was registered in the State Register in 2003, Chornobrova (hard black winter)- in 2014, two varieties of winter soft wheat: (soft white winter) wheat - Belyava from 2015 and Oksana (soft red winter) in the varieties register since 2007, Sofiika (hard red winter waxy) - in 2015. Belyava, Chornobrova, Oksana and Sofiika were bred by A. Rybalko at the Breeding and Genetic Institute. Spelt wheat represented by: 2 samples Spelt (white winter) grown in 2017 and 2018, and one sample Spelt (red winter) grown in 2018.

To assess the rheological properties of flour obtained from grain, it is necessary to produce grinding in a CD1 (ISO 27971) type mill consisting of two parts: break and reduction and flour granulometry not higher than 160 $\mu \mathrm{m}$. Water-thermal processing of the grain before it's grinding carried out in accordance with ISO 27971 standard.

Water absorption capacity (WAC) was determined on device mixolab within 45 minutes in accordance with the international standard ICC 173/1.

Dough rheological analysis which was consisted of flour $(250 \mathrm{~g})$, sodium chloride solution $2.5 \%$ (depending on moisture content). The amount of added water is initially calibrated directly as a percentage of dough moisture and in a result mass of the dough is different. Alveograph test performed using an alveograph (Chopin (NG), France) following the AACC method ISO 27971:2008. A computer software program automatically recorded the following alveograph parameters: resistance to extension $(\mathrm{P})$, dough extensibility $(\mathrm{L})$, curve configuration ratio $(\mathrm{P} / \mathrm{L}$ ratio), the deformation energy $(\mathrm{W})$ and elasticity (P200/P ratio).

To determine the rheological properties on the alveograph, taking into account the WAC, we recalculated the amount of added water. The burette used to add water is initially calibrated directly as a percentage of dough moisture and according to our calculation for $\mathrm{WAC}=53 \%$.

\section{Results and discussion}

The Chopin Alveograph is a test commonly used overseas to help determine the baking potential of wheat by measuring its characteristics, that provides in formation on the following:

a) the resistance of the dough to deformation, or its strength. It is expressed by the maximum pressure parameter, $\mathrm{P}$;

A

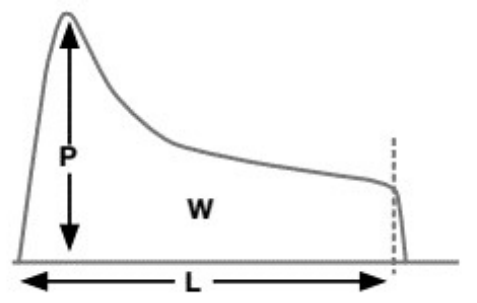

$\mathrm{B}$

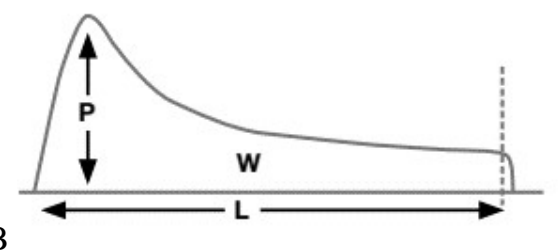

b) the extensibility or the possibility of inflating the dough to form a bubble; It is expressed by the parameters of extensibility, L, or swelling, G;

c) the elasticity of the dough during biaxial extension. It is expressed by the elasticity index, Ie;

d) the work required to deform the dough bubble until it ruptures, which is proportional to the area of the alveogram (sum of the pressures throughout the deformation process). It is expressed by the parameter, $\mathrm{W}$.

The $\mathrm{P} / \mathrm{L}$ ratio is a measurement of the balance between strength and extensibility.

Alveograph allows to compare, select and classify the different batches of wheat available on the market according to their future use (fig.1), described in Agriculture and Horticulture Development Board (2017).

According to this classification there are three wheat grain groups:

a) suitable for bread flour (fig.1 A) - makes strong elastic dough and has breadmaking potential. Characterized by high pressure $(\mathrm{P})$ and long time (L) to burst. Typical range: $\mathrm{P} / \mathrm{L} \sim 0.9, \mathrm{~W}>170 \cdot 10^{-4} \mathrm{~J}$;

b) suitable for biscuit and blending flour (FIG.1 B) - makes extensible dough, good for biscuits and blending with strong wheats. Characterized by low pressure $(\mathrm{P})$ and long time $(\mathrm{L})$ gives a lower $\mathrm{P} / \mathrm{L}$, area under the curve $(\mathrm{W})$ less critical. Typical range: $\mathrm{P} / \mathrm{L} \sim 0.55$, $\mathrm{W}=80-120 \cdot 10^{-4} \mathrm{~J}$

c) suitable for animal feed only flour (FIG.1 C) makes tough, inelastic dough. Characterized by high pressure $(\mathrm{P})$ and short time $(\mathrm{L})$ to burst. Typical range: $\mathrm{P} / \mathrm{L}=0.3-1.5, \mathrm{~W}=60-140 \cdot 10^{-4} \mathrm{~J}$.

At the same time, baking wheat by strength on the alveograph can be divided into the following groups:

a) $\mathrm{W}=170-200 \cdot 10^{-4} \mathrm{~J}-$ low baking properties;

b) $\mathrm{W}=200-250 \cdot 10^{-4} \mathrm{~J}-$ good baking properties;

c) $\mathrm{W}>250 \cdot 10^{-4} \mathrm{~J}-$ high baking properties.

Thus, according to the standard test, flour with $\mathrm{W}>200 \cdot 10^{-4} \mathrm{~J}, \mathrm{P} / \mathrm{L}=0.8-1.2$ has good baking properties.

Flour from wheat Kuyalnik is the benchmark of common bakery wheat and according to the results of standard alveogram has the highest strength (W) and elasticity (Ie) of all samples (Table 2, Figure 2). The wheat with $\mathrm{W}=439 \cdot 10^{-4} \mathrm{~J}$ corresponds to strong wheat with optimal curve configuration $\mathrm{P} / \mathrm{L}=1.11$.

The addition of water in accordance with the WAC softens the dough $\mathrm{W}=260 \cdot 10^{-4} \mathrm{~J}$; respectively, the resistance of the dough to deformation and the extensibility decreases, but without changing the coefficient of curve configuration and elasticity $(\mathrm{P} / \mathrm{L}=0.94, \mathrm{Ie}=68.4 \%)$ and it $\mathrm{s}$ still optimal for bakery purposes.

Chornobrova obtained by crossing Kuyalnik and wild wheat of Chinese origin Dong 10. Flour from wheat Chornobrova, according to the standard test on

Fig. 1. Typical characteristics of different wheat application

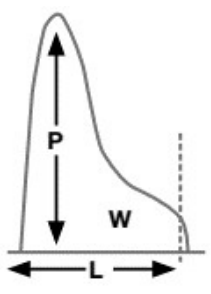




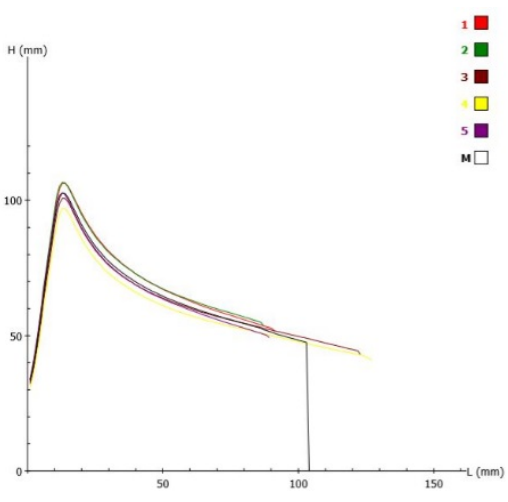

$\mathbf{A}$

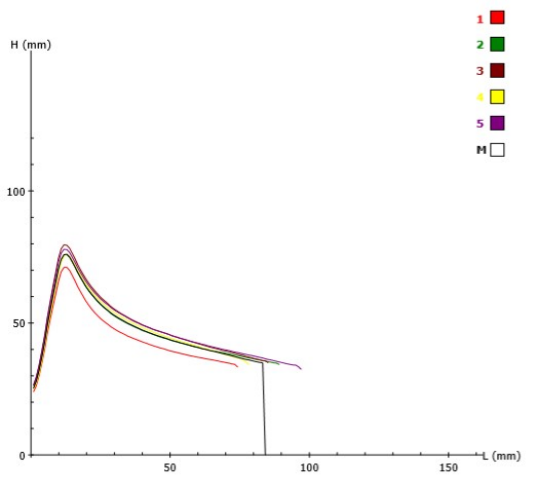

C

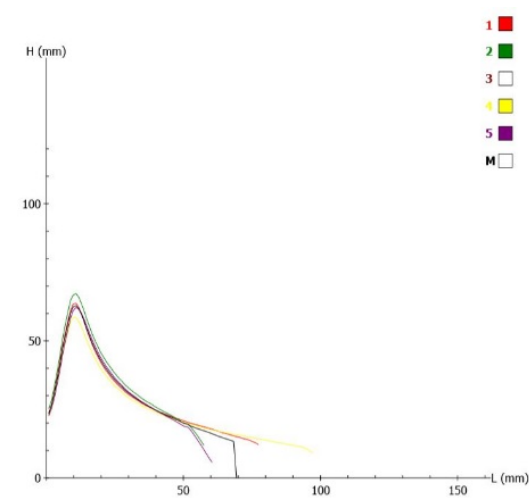

B

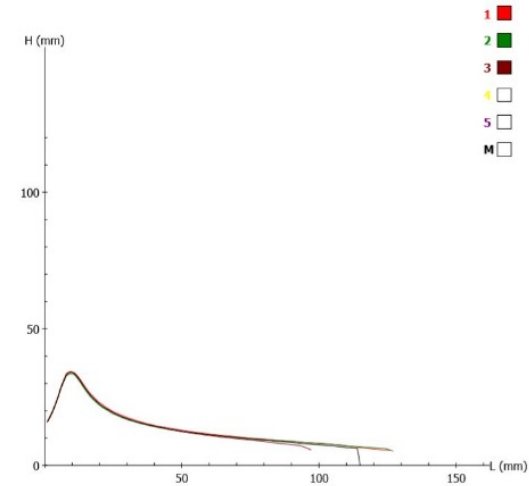

D
Fig. 2. Results of standard alveograph test of Kuyalnik (A) and Chornobrova (B) wheat and alveograph test with adapted moistening of Kuyalnik (C) and Chornobrova (D) wheat

alveograph, has weak baking properties: all indicators are lower compared to Kuyalnik, resistance to extension $(\mathrm{P}=69 \mathrm{~mm})$, extensibility $(\mathrm{L}=67 \mathrm{~mm})$ and elasticity $(\mathrm{Ie}=39.0 \%)$ are lower respectively in $1.2,1.5,1.7$ times (Table 2, Figure 2). When assessing the alveograph for adaptive moistening, the addition of water lowers indicator P by 1.9 times and almost in 1.8 times increases indicator L, increasing swelling, but the elasticity of the test remains the same low ( $\mathrm{Ie}=40.4$ ).

Flour from soft wheat is expected to have average baking properties $\left(\mathrm{W}>155 \cdot 10^{-4} \mathrm{~J}\right)$, in all respects it is slightly better than Chornobrova (Table 2, Figure 3). Adaptive moistening, unlike the sharp deterioration of Chornobrova, does not alter the properties of the Belyava and Oksana test, due to the low WAC value (53.8\% and 54.0\%).

Waxy wheat flour has potentially high baking properties (Table 2, Figure 3). High indicator of strength $\mathrm{W}=205 \cdot 10^{-4} \mathrm{~J}$, high $\mathrm{P}-$ in 1.7 times more than Kuyalnik, but in 4.4 times very low extensibility L. Since L is less than $40 \mathrm{~cm}-$ elasticity cannot be determined. This is due to a very high WAC $=$ $66.9 \%-1.1$ times more than Kuyalnik. A high WAC value results from high damage to starch grains and this could be owing to greater susceptibility of waxy wheat to mechanical damage during milling (Bettge et al. 2000). As a result, $\mathrm{P} / \mathrm{L}$ is much higher $(8.3)$ than the recommended $\mathrm{P} / \mathrm{L}$ ratio for bread production $(\mathrm{P} / \mathrm{L}=0.8$ 1.2). For Sofiika, the test on the alveograph with the WAC gave her more water, which led to an increase in elasticity $(\mathrm{Ie}=52.4 \%)$ and extensibility $(\mathrm{L}=77 \mathrm{~mm})$ with average strength $\mathrm{W}=150 \cdot 10^{-4} \mathrm{~J}$, as a consequence, and leading to an optimal $\mathrm{P} / \mathrm{L}$ ratio $(\mathrm{P} / \mathrm{L}=0.74)$ that was more suitable for the bake bread $(\mathrm{P} / \mathrm{L}=0.8-1.2)$.

All flour from the samples of Spelt (Table 2, Figure 4) has low strength $\mathrm{W}=50-62 \cdot 10^{-4} \mathrm{~J}$, low elasticity $\mathrm{Ie}=21.7-29.5 \%$ and low baking capacity. As a result, they have lower $\mathrm{P} / \mathrm{L}$ ratio $0.25-0.50$ and unsuitable (fluid, sticky) test consistency. All samples of Spelt with adaptive moistening showed similar result - its decrease resistance to extension (P) and increase of extensibility (L). In a result we observe decrease of $\mathrm{P} / \mathrm{L}$ ratio to $0.18-0.29$, thus indicating extremely extensible doughs with very little elasticity. Cubadda and Marconi (1996) described a high baking quality of spelt wheat in their study, despite spelt wheat gluten being less tough or firm and provoking worse rheological properties of dough than bread

Table 2. Results of determining of rheological properties on alveograph and WAC* on mixolab

\begin{tabular}{|c|c|c|c|c|c|c|c|c|c|c|c|c|c|}
\hline \multirow[b]{2}{*}{ Sample } & \multicolumn{6}{|c|}{ Alveograph } & \multirow{2}{*}{$\begin{array}{c}\text { WAC*, } \\
\%\end{array}$} & \multicolumn{6}{|c|}{ Alveograph WAC* } \\
\hline & $\begin{array}{c}\mathrm{P}, \\
\mathrm{mm}\end{array}$ & $\begin{array}{c}\mathrm{L}, \\
\mathrm{mm}\end{array}$ & $\mathrm{P} / \mathrm{L}$ & $\begin{array}{c}\mathrm{W} \\
10^{-4} \mathrm{~J} \\
\end{array}$ & $\mathrm{G}$ & $\begin{array}{l}\text { Ie, } \\
\%\end{array}$ & & $\begin{array}{c}\mathrm{P}, \\
\mathrm{mm}\end{array}$ & $\begin{array}{c}\mathrm{L}, \\
\mathrm{mm}\end{array}$ & $\mathrm{P} / \mathrm{L}$ & $\begin{array}{c}\mathrm{W}, \\
10^{-4} \mathrm{~J} \\
\end{array}$ & G & $\begin{array}{l}\text { Ie, } \\
\%\end{array}$ \\
\hline Kuyalnik & 113 & 102 & 1,11 & 439 & 22,5 & 67,6 & 58,7 & 74 & 70 & 0,94 & 260 & 18,9 & 68,4 \\
\hline Chornobrova & 69 & 67 & 1,03 & 137 & 18,2 & 39,0 & 56,0 & 37 & 114 & 0,32 & 104 & 23,8 & 40,4 \\
\hline Belyava & 64 & 79 & 0,81 & 162 & 19,8 & 49,0 & 53,8 & 61 & 88 & 0,69 & 167 & 20,9 & 49,1 \\
\hline Oksana & 64 & 86 & 0,74 & 155 & 20,3 & 42,4 & 54,0 & 60 & 98 & 0,61 & 165 & 22,0 & 45,2 \\
\hline Sofiika & 191 & 23 & 8,30 & 205 & 10,7 & 0,0 & 66,9 & 57 & 77 & 0,74 & 150 & 19,5 & 52,4 \\
\hline White Spelt 1 & 31 & 62 & 0,50 & 50 & 17,5 & 28,9 & 51,0 & 30 & 104 & 0,29 & 63 & 22,7 & 30,3 \\
\hline White Spelt 2 & 30 & 118 & 0,25 & 62 & 24,2 & 29,5 & 52,5 & 28 & 130 & 0,22 & 58 & 25,4 & 27,6 \\
\hline Red Spelt & 36 & 69 & 0,52 & 52 & 18,5 & 21,7 & 54,4 & 22 & 119 & 0,18 & 41 & 24,3 & 24,6 \\
\hline
\end{tabular}

*WAC - water absorption capacity on the moisture content $14 \%$. 


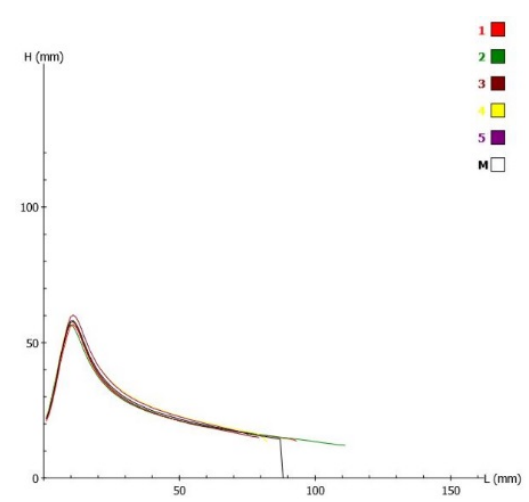

A

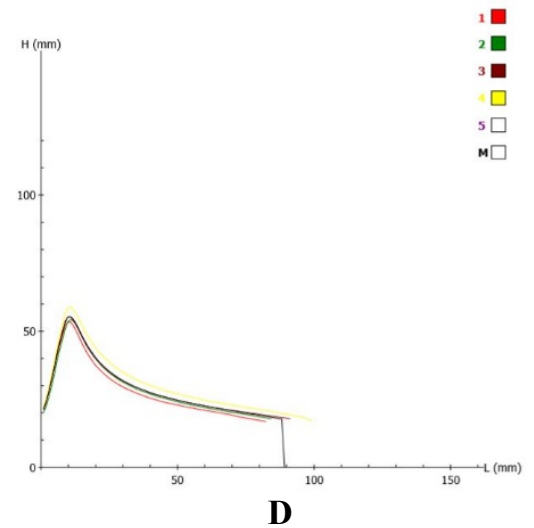

Fig. 3. Results of standard alveograph test of Belyava (A), Oksana (B),

Sofika $(C)$ wheat and alveograph test with adapted moistening of Belyava (D), Oksana (E), Sofika (F) wheat

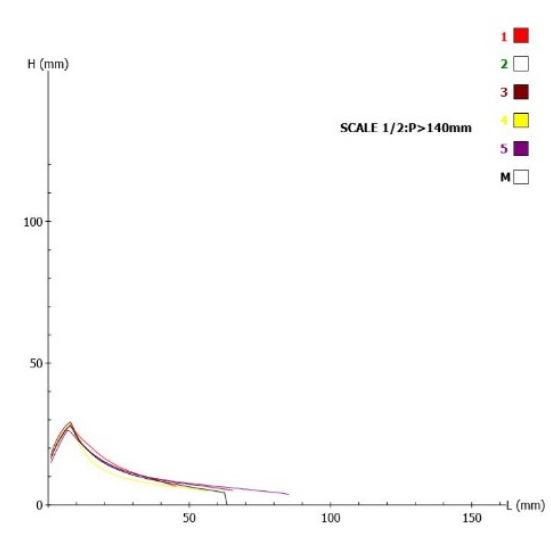

A

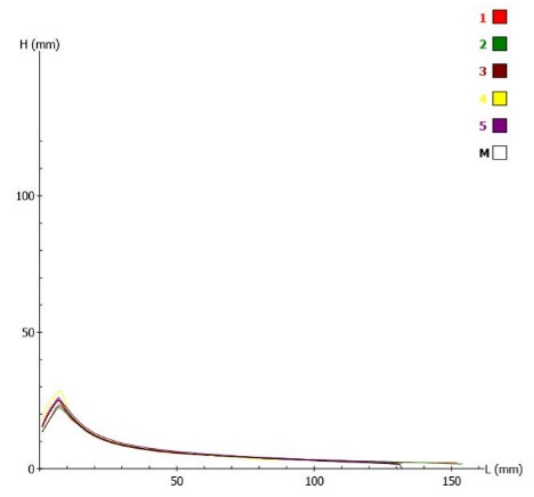

D

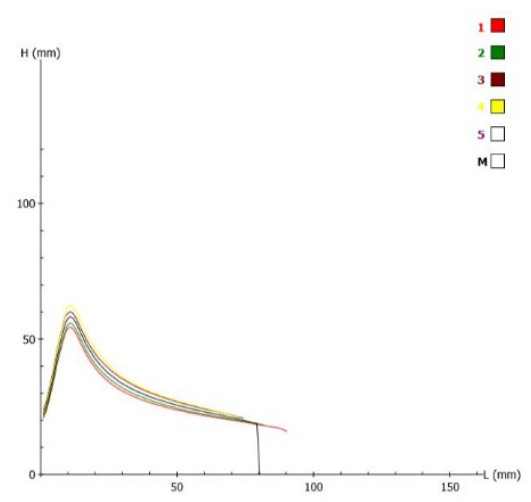

B

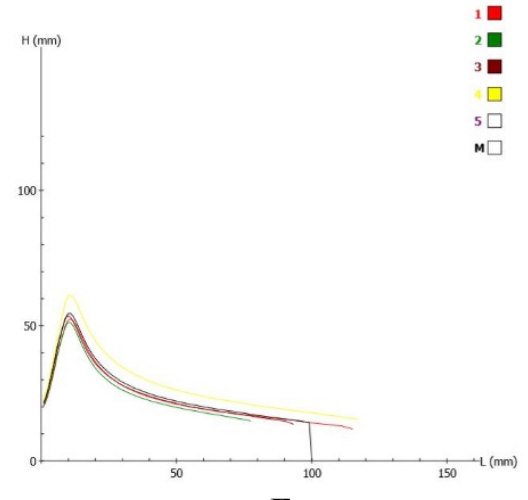

$\mathbf{E}$

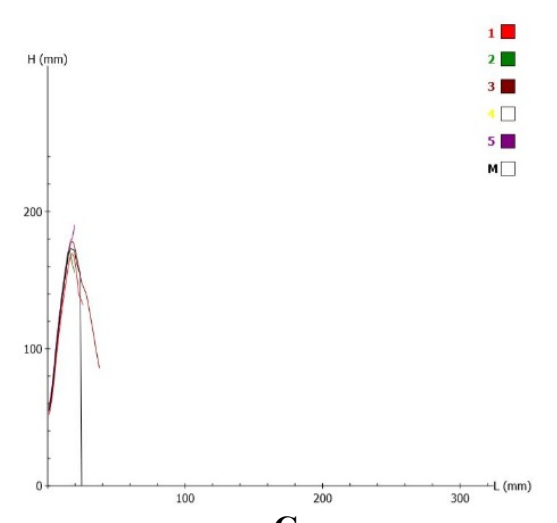

C

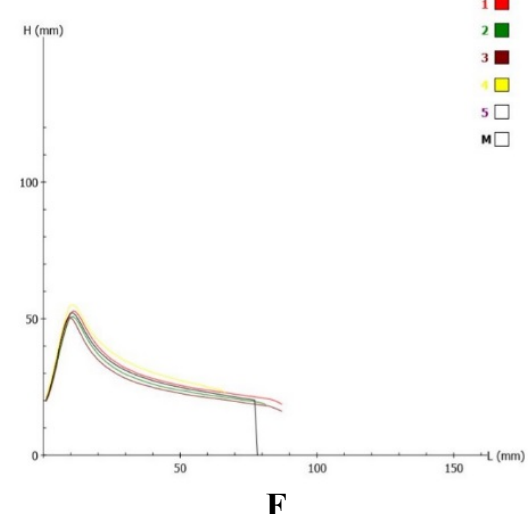

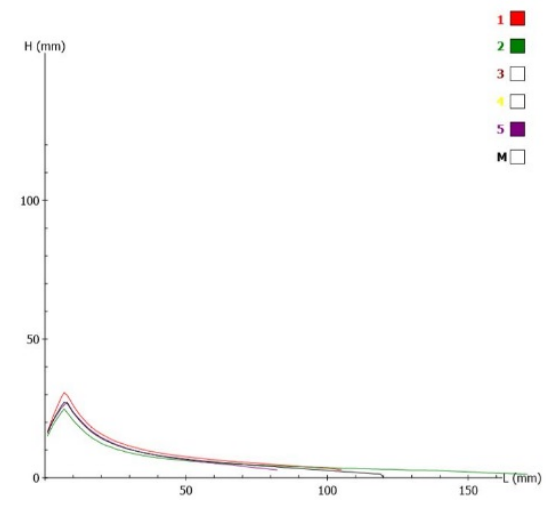

B

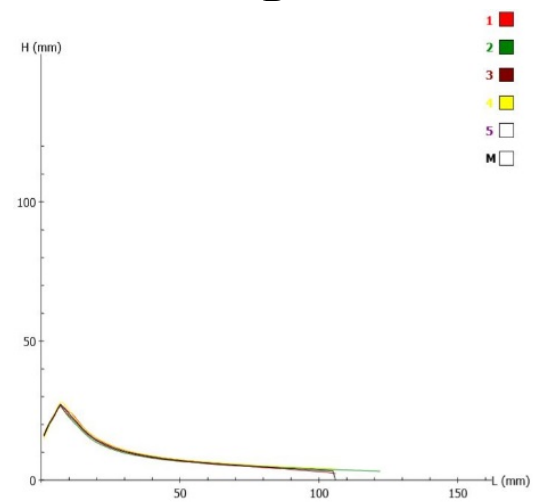

$\mathbf{E}$

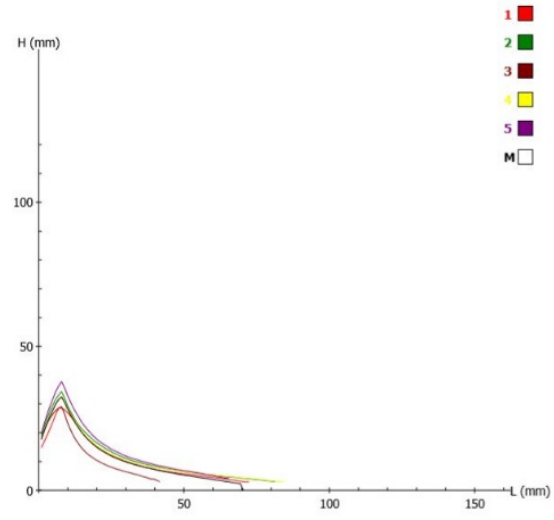

C

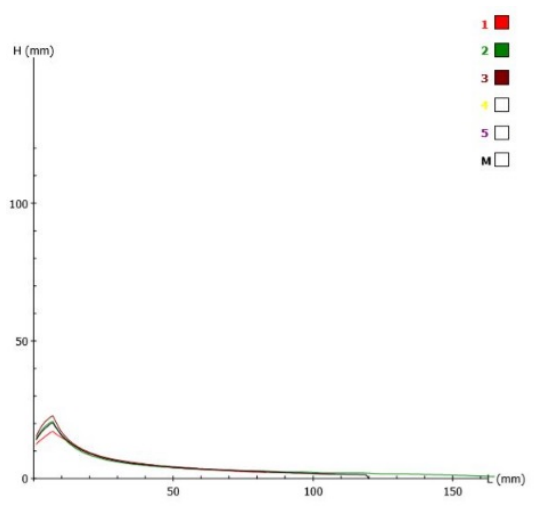

F

Fig. 4. Results of standard alveograph test of White Spelt 1 (A), White Spelt 2 (B), Red Spelt $(C)$ wheat and alveograph test with adapted moistening of White Spelt 1 (D),

White Spelt 2 (E), Red Spelt (F) wheat 
wheat one (Schmitz, K. 2006). Therefore, it is highly advisable to use a mixture of spelt wheat and bread wheat flour for the production of bakery products.

Comparing the standard and the method with adaptive hydration, we see that for all samples with adapted moistening a decrease in resistance to extension (P) and an increase in extensibility (L) are observed, in a result of the decline in the $\mathrm{P} / \mathrm{L}$ ratio. Strength of flour (W) almost in all samples became less. The largest change was shown by the samples: Kuyalnik - decrease of $\mathrm{W}$ in 1.68 times; Chornobrova - decrease of $\mathrm{P}$ in 1.86 times, increase of $\mathrm{L}$ in 1.7 times and in a result decrease $\mathrm{P} / \mathrm{L}$ in 3.2 times; Sofiika - decrease of $\mathrm{P}$ in 3.4 times, increase of $\mathrm{L}$ in 3.3 times and in a result decrease $\mathrm{P} / \mathrm{L}$ in 11.2 times.

\section{Conclusions}

According to the totality of the Kuyalnik wheat data obtained in our experiment, it can conclude that it is typical bakery wheat, and the results of the experiments corresponded to the values characteristic for hard wheat with greater $\mathrm{W}$ of flour. Adaptive moistening will show the change in $\mathrm{P}$ and $\mathrm{L}$ and the $\mathrm{P} / \mathrm{L}$ ratio in real cooking conditions, since the standard alveograph test assesses the potential of wheat. By adjusting the amount of water, we can achieve optimal dough characteristics for different products.

The results of studies of wheat Chornobrova correlate with the results of wheat Kuyalnik, but the baking properties were worse. Adaptive moistening is not recommended for her. Therefore, this wheat can be recommended for making bakery products when added in a mixture with patent flour, in an amount up to $20-30 \%$ (requires further study).

Flour from soft wheat differs significantly from hard wheat. For soft wheat, adaptive moistening is not necessary, because the WAC and moisture content are the same, and according to the standard of the experiment, the moisture conversion to the added amount of water is calculated for soft wheat. Soft wheat flour can add to special types of bread to give a lighter color to the crumb, but in a small amount (no more than $10-20 \%$ ) or recommended for making cookies.

Based on the results of a standard test on alveograph Sofiika has a high baking potential. However, the addition of water according to WAC leads to the formation of a very soft dough and this distorts its actual baking ability. Perhaps, in the conditions of real test science and laboratory analysis on the alveograph, it is necessary to add a smaller amount of water by $2-3 \mathrm{ml}$, which requires a more detailed research. When determining on the alveograph, the dough is very tight due to low content of water. It is advisable to carry out an alveograph test with adapted moistening for waxy wheat, that giving it more water, which leads to an increase in elasticity and extensibility, as a consequence, and leading to an optimal $\mathrm{P} / \mathrm{L}$ ratio that was more suitable for the bake bread. Based on its special application, it is necessary to develop specific recommendations for determining its properties on the alveograph. However, in any case waxy wheat recommended for the production of pasta.

The Spelt flour has less strength, low elasticity and low baking ability. With such values of rheological characteristics, the use of flour is limited as a raw material for confectionery, waffle products, spice-cakes, cupcakes, which are characterized by a viscous or viscousplastic dough. Also, flour can be added as an improverto relax the dough. Therefore, it is highly advisable to use a mixture of spelt wheat and bread wheat flour for the production of bakery products.

\section{REFERENCES}

1. Abbasi, H., Emam-Djomeh, Z., Seyedin, S.M. (2011). Application of Artificial Neural Network and Genetic Algorithm for Predicting three Important Parameters in Bakery Industries. International Journal of Agricultural Science and Research 2(4): 51-64.

2. Abdel-Aal, E.S.M., Sosulski, F.W., Hucl, P. (1998). Origins, characteristics, and potentials of ancient wheats. Cereal Foods World, 43(9), 708-715.

3. Abdel-Aal, E.-S. M., Hucl, P., Chibbar, R. N., Han, H. L., and Demeke, T. (2002). Physicochemical and structural characteristics of flours and starches from waxy and nonwaxy wheats. Cereal Chem. 79:458-464

4. Berti C., Riso P., Brusamolino A., Porrini M. (2005). Effect on appetite control of minor cereal and pseudocereal products. British J. Nutr. 94, 850-858.

5. Bushuk, W. and Békés, F. (2002). Contribution of Protein to Flour Quality. In: Salgo, A., Tomoskozi, S. and Lasztity, R., Eds., Proc. Novel Raw Materials, Technologies and Products-New Challenge for the Quality Control. International Association for Cereal Science and Technology (ICC), Budapest, 14-19.

6. Campbell K.G. (1997). Spelt: agronomy, genetics and breeding. Plant Breed. Rev. 15, 187-213.

7. Chakraborty, M., Matkovic, K., Grier, D.G., Jarabek, E.L., Berzonsky, W.A., McMullen, M.S., et al. (2004). Physicochemical and functional properties of tetraploid and hexaploid waxy wheat starch. Starch/Sta"rke, 56, 339-347.

8. Chibbar, R.N., Baga, M., Demeke, T., Hucl, P. (1997). Genetic engineering for starch modification. In J. L. Steele \& O. K. Chung (Eds.), Proceedings of international wheat quality conference (pp. 245-259). Manhattan, KS: Grain Industry Alliance.

9. Colombo, A., Perez, G.T., Ribotta, P.D., Leon, A.E. (2008). A comparative study of physicochemical tests for quality prediction of Argentine wheat flours used as corrector flours and for cookie production. Journal of Cereal Science 48(3): 775-780.

10. Delcour, J.A., and Hoseney, R.C. (2010). Principles of Cereal Science and Technology, 3rd ed. St. Paul, MN: AACC International.

11. Graybosch, R. A. (1998). Waxy wheats: Origin, properties, and prospects. Trends Food Sci. Technol. 9:135-142.

12. Khattak, S., D'appolonia, B.L., and Banasik, O.J. (1974). Use of the alveograph for quality evaluation of hard red spring wheat. Cereal Chem. 5 1:355.

13. Kiribuchi-Otobe, C., Nagamine, T., Yanagisawa, T., Ohnishi, M., Yamaguchi, I. (1997). Production of hexaploid wheats with waxy endosperm character. Cereal Chemistry, 74, 72-74.

14. Morrison, W.R., Milligan, T.P., Azudin, M.N. (1984). A relationship between the amylose and lipid contents of starches from diploid cereals. Journal of Cereal Science, 2, 257-271. 
15. Onishi I., Hongo A., Sasakuma T., Tawahara T., Kato K., Miura H. (2006). Variation and segregation for rachis fragility in spelt wheat, Triticum spelta L. Gen. Res. Crop Evol. 53, 985-992.

16. Posner, E. (2000). Wheat. In: Kulp, K. E. A. (ed.) Handbook of Cereal Science and Technology. New York: Marcel Dekker.

17. Preston, K.R.; Lukow, O.M.; Morgan, B. (1992). Analysis of relationships between flour quality properties and protein fractions in a world wheat collection. Cereal Chem, 69, 560-567.

18. Shewry, P.R. (2009). Wheat. Journal of Experimental Botany, 60(6), 1537-1553.

19. Song, Y. and Zheng, Q. (2007). Dynamic rheological properties of flour dough and proteins wheat. Trends in Food Science \& Technology 18(3): 132-138.

20. Toporash I., Rybalka O., Lytvynenko M., Surzhenko I. (2008). Tsikavi zakonomirnosti vyplyvaiut z doslidzhen-nia boroshnomelnykh vlastyvostei suchasnykh sortiv pshenytsi. Zerno i khlib. №1(49): 50-51.

21. Yan Y., Hsam S.L.K., Yu J.Z., Jiang Y., Ohtsuka I., Zeller F.J. (2003). HMW and LMW glutenin alleles among putative tetraploid and hexaploid European spelt wheat (Triticum spelta L.) progenitors. Theor. Appl. Genetic 107, 1321-1330.

22. Zieliński H., Ceglińska A., Michalska A. (2008). Bioactive compounds in spelt bread. Eur. Food Res. Technol. 226, $537-$ 544.

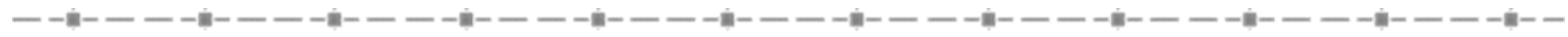

УДК [664.641.12-026.761:664.64.016.8]

Д.о. Жигунов ${ }^{1}$, д-р техн. наук, доцент, E-mail: dimius75@gmail.com https://orcid.org/0000-0001-9435-2266, ResearcherID: D-1372-2015, Scopus Author ID: 55820666600 I.Г. Топораш ${ }^{2,3}$, канд. техн. наук, E-mail: itoporash@controlunion.com https://orcid.org/0000-0001-5165-8070

Ю.С. Барковська ${ }^{1,2}$, Магістр, E-mail: ellion.vent@gmail.com https://orcid.org/0000-0001-8627-8721

С.О. Сгоршин ${ }^{1}$, Магістр, E-mail: yevheniiyehorshyn@gmail.com https://orcid.org/0000-0003-3038-0254

${ }^{1}$ Одеська національна академія харчових технологій, вул. Канатна, 112, Одеса, 65039, Україна 2 ДП Agmintest Control Union, Овідіопольска дор., 3, Одеса, 65036, Украӥна 3 Селекиійно-генетичний інститут - Національний цеентр насіннєзнавства та сортовивчення, Овідіопольска дор., 3, Одеса, 65036, Украӥна

\section{ПОРІВНЯННЯ ХАРАКТЕРИСТИК БОРОШНА 3 РІЗНИХ ТИПІВ ЗВИЧАЙНОЇ ПШЕНИЦІ ТА СПЕЛЬТИ НА АЛЬВЕОГРАФІ}

\section{Анотація}

У світі широко поширена практика переробки нових видів пшениці, але майэе невідома в крайнах СНД, оскільки селекиія протягом багатьох років була спрямована на отримання виключно високобілкових хлібопекарських сортів пшениці. Тому невідомо, якими технологічними властивостями володіє борошно з сортів пшениці спеціального призначення, $і$ щэо потрібно враховувати при здрібненні та використанні такої сировини.

Альвеограф вимірюе в'язкопружні властивості тіста з пшеничного борошна. Відповідно до стандартного методу ISO 27971, кількість доданої води калібрується у перерахунку на вологість борошна. Цей метод розроблений для стандартних видів борошна і може бути непридатним для очінки реологічних властивостей борошна з нових типів пшениці з різною водопоглинальною здатністю, тому слід вивчити методику їх проведення та при необхідності адаптувати.

Для вивчення взаємозв'язку між водопоглинальною здатністю та в'язкопружними властивостями тіста на Альвеографі були проведені дослідження на восьми зразках борошна, отриманих з різних типів пшенииі. Дослідження були проведені з використанням стандартного тесту (розрахованого на борошно з ВП3=53\%) та тесту з адаптивним зволоженням, для чого було перераховано кількість доданої води відповідно до водопоглинальної здатності (ВПЗ) борошна, яку визначали на міксолабі.

Борошно із звичайної твердозерної червоної пшениці (Куяльник) є еталоном звичайної хлібопекарської пшениці $і$ за результатами стандартного тесту на альвеографі мало найвищу, з усіх зразків, силу (W) та еластичність (Іе). Пшеницю зі значенням $W=439 \cdot 10^{-4} \mathrm{~J}$ можна віднести до сильних пшениць ( $\left.W>200 \cdot 10^{-4} \mathrm{~J}\right)$. Додавання води відповідно до ВПЗ борошна пом'якшило тісто $W=60 \cdot 10^{-4} \mathrm{~J}$, але воно залишилося оптимальним для хлібопекарських иілей. Результати досліджень звичайної чорної пшениці (Чорноброва) співвідносяться з результатами пшениці Куяльник, але ї̈ хлібопекарські властивості були гіриими.

Для ваксі пшениці (Софійки) тест на альвеографі з адаптивним зволоженням дав їй більше води, щяо призвело до збільшення еластичності (Ie=52.4\%) та розтяжності $(L=77$ мм) i до оптимального значення співвідношення $P / L(0.74)$, щяо є більш зручним для випічки хліба (0.8-1.2).

Борочно з м'якозерної пшениці, очікувано мало середні хлібопекарські властивості $\left(W>155 \cdot 10^{-4} \mathrm{~J}\right)$, але в усіх відношеннях воно було трохи кращим за борошно з пшениці Чорноброва. Адаптивне зволоження, на відміну від різкого погіршення реологічних характеристик тіста з Чорноброви, не змінило властивості тіста з Біляви та Оксани у зв'язку з низьким значенням ВПЗ (53.8\% та 54.0\%). Пиеничне борошно зі Спельти мало низьку силу (W=50-62.10 $\left.0^{-4} \mathrm{~J}\right)$, низьке співвідношення $P / L=0.25$-0.50 та невідповідну (рідку та липку) консистенцію тіста. Всі зразки Спельти з адаптивним зволоженням показали однакові результати - зменшення показника пружності (P) та підвищення розтяжності (L). B результаті ми отримали зменшення співвідношення P/L до 0.18-0.29, ие вказує на надзвичайно розтяжне тісто з дуже низькою еластичністю.

Для всіх зразків при адаптивному зволоженні, спостерігається зменшення стійкості до розширення (P) та збільшення розтяжності $(L)$, в результаті $і$ зниження $P / L$ співвідношення. Для пшениці Куяльник адаптивне зволоження краще показує як змінюеться $P, L$ та співвідношення $P / L$ в реальних умовах тістоведення, тоді як стандартний тест на альвеографі показує лише потенціал пшениці. Регулюючи кількість води, ми можемо досягти оптимальних характеристик тіста для виготовлення різних продуктів. Для м'якозерної пшениці та спельти, адаптивне зволоження не є необхідним, оскільки 
значення ВПЗ та вологості такі ж, як для стандартного експерименту. Для ваксі пшенииі доиільним є проведення тесту на альвеографі з адаптивним зволоженням, що дає їи більше води і призводить до збільшення еластичності та розтяжноcті, $і$ як наслідок до оптимального співвідношення $P / L$, зручного для випічки хліба (0.8-1.2). Грунтуючись на ї̈ спеціальному застосуванні, необхідно розробити конкретні рекомендації щодо визначення реологічних властивостей на альвеографі.

Ключові слова: пшениця, спельта, пшеничне борочно, міксолаб, альвеограф, водопоглинальна здатність, реологічні властивості, адаптивне зволоження.

\section{ЛITEPAТУРА}

1. Abbasi, H., Emam-Djomeh, Z., Seyedin, S.M. (2011). Application of Artificial Neural Network and Genetic Algorithm for Predicting three Important Parameters in Bakery Industries. International Journal of Agricultural Science and Research 2(4): 51-64.

2. Abdel-Aal, E.S.M., Sosulski, F.W., Hucl, P. (1998). Origins, characteristics, and potentials of ancient wheats. Cereal Foods World, 43(9), 708-715.

3. Abdel-Aal, E.-S. M., Hucl, P., Chibbar, R. N., Han, H. L., and Demeke, T. (2002). Physicochemical and structural characteristics of flours and starches from waxy and nonwaxy wheats. Cereal Chem. 79:458-464

4. Berti C., Riso P., Brusamolino A., Porrini M. (2005). Effect on appetite control of minor cereal and pseudocereal products. British J. Nutr. 94, 850-858.

5. Bushuk, W. and Békés, F. (2002). Contribution of Protein to Flour Quality. In: Salgo, A., Tomoskozi, S. and Lasztity, R., Eds., Proc. Novel Raw Materials, Technologies and Products-New Challenge for the Quality Control. International Association for Cereal Science and Technology (ICC), Budapest, 14-19.

6. Campbell K.G. (1997). Spelt: agronomy, genetics and breeding. Plant Breed. Rev. 15, 187-213.

7. Chakraborty, M., Matkovic, K., Grier, D.G., Jarabek, E.L., Berzonsky, W.A., McMullen, M.S., et al. (2004). Physicochemical and functional properties of tetraploid and hexaploid waxy wheat starch. Starch/Sta rke, 56, 339347.

8. Chibbar, R.N., Baga, M., Demeke, T., Hucl, P. (1997). Genetic engineering for starch modification. In J. L. Steele \& O. K. Chung (Eds.), Proceedings of international wheat quality conference (pp. 245-259). Manhattan, KS: Grain Industry Alliance.

9. Colombo, A., Perez, G.T., Ribotta, P.D., Leon, A.E. (2008). A comparative study of physicochemical tests for quality prediction of Argentine wheat flours used as corrector flours and for cookie production. Journal of Cereal Science 48(3): 775-780.

10. Delcour, J.A., and Hoseney, R.C. (2010). Principles of Cereal Science and Technology, 3rd ed. St. Paul, MN: AACC International.

11. Graybosch, R. A. (1998). Waxy wheats: Origin, properties, and prospects. Trends Food Sci. Technol. 9:135-142.

12. Khattak, S., D'appolonia, B.L., and Banasik, O.J. (1974). Use of the alveograph for quality evaluation of hard red spring wheat. Cereal Chem. 5 1:355.

13. Kiribuchi-Otobe, C., Nagamine, T., Yanagisawa, T., Ohnishi, M., Yamaguchi, I. (1997). Production of hexaploid wheats with waxy endosperm character. Cereal Chemistry, 74, 72-74.

14. Morrison, W.R., Milligan, T.P., Azudin, M.N. (1984). A relationship between the amylose and lipid contents of starches from diploid cereals. Journal of Cereal Science, 2, 257-271.

15. Onishi I., Hongo A., Sasakuma T., Tawahara T., Kato K., Miura H. (2006). Variation and segregation for rachis fragility in spelt wheat, Triticum spelta L. Gen. Res. Crop Evol. 53, 985-992.

16. Posner, E. (2000). Wheat. In: Kulp, K. E. A. (ed.) Handbook of Cereal Science and Technology. New York: Marcel Dekker.

17. Preston, K.R.; Lukow, O.M.; Morgan, B. (1992). Analysis of relationships between flour quality properties and protein fractions in a world wheat collection. Cereal Chem., 69, 560-567.

18. Shewry, P.R. (2009). Wheat. Journal of Experimental Botany, 60(6), 1537-1553.

19. Song, Y. and Zheng, Q. (2007). Dynamic rheological properties of flour dough and proteins wheat. Trends in Food Science \& Technology 18(3): 132-138.

20. Топораш I., Рибалка О., Литвиненко М., Сурженко I. (2008). Цікаві закономірності випливають 3 дослідження борошномельних властивостей сучасних сортів пшениці. Зерно і хліб. №1 (49): 50-51.

21. Yan Y., Hsam S.L.K., Yu J.Z., Jiang Y., Ohtsuka I., Zeller F.J. (2003). HMW and LMW glutenin alleles among putative tetraploid and hexaploid European spelt wheat (Triticum spelta L.) progenitors. Theor. Appl. Genetic 107, 13211330.

22. Zieliński H., Ceglińska A., Michalska A. (2008). Bioactive compounds in spelt bread. Eur. Food Res. Technol. 226, 537-544.

Received 10.01.2020

Reviewed 03.02.2020
Revised 26.02.2020

Approved 03.03.2020

Cite as Vancouver Citation Style

Zhygunov D., Toporash I., Barkovska Y., Yehorshyn Y. Comparison of alveograph characteristic of flour obtained from different types of common wheat and spelt wheat. Grain Products and Mixed Fodder's, 2020; 20 (1, 77): 23-30. DOI:

Cite as State Standard of Ukraine 8302:2015

Comparison of alveograph characteristic of flour obtained from different types of common wheat and spelt wheat / Zhygunov D. et al. // Grain Products and Mixed Fodder's. 2020. Vol. 20, Issue1 (77). P. 23-30. DOI:

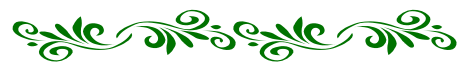

